\title{
Hepatitis E Prevalence, Knowledge, and Practice of Preventive Measures Among Adolescents In Rural Nigeria: A Cross-Sectional Study
}

Chioma Ngozichukwu Pauline Mbachu ( $\sim$ chiomambachupauline@gmail.com )

Nnamdi Azikiwe University https://orcid.org/0000-0001-7030-5828

Joy Chinelo Ebenebe

Nnamdi Azikiwe University

Henry Chima Okpara

Nnamdi Azikiwe University

John Onuora Chukwuka

Nnamdi Azikiwe University

Ikechukwu Innocent Mbachu

Nnamdi Azikiwe University

Jacinta Chinyere Elo-llo

Nnamdi Azikiwe University

Chizalu Ifeyinwa Ndukwu

Nnamdi Azikiwe University

Ifeoma Egbuonu

Chukwuemeka Odumegwu Ojukwu University

Research article

Keywords: Hepatitis E, adolescents, prevalence, knowledge, practice, Nigeria

Posted Date: February 17th, 2021

DOI: https://doi.org/10.21203/rs.3.rs-243925/v1

License: (1) (1) This work is licensed under a Creative Commons Attribution 4.0 International License. Read Full License 


\section{Abstract}

Background: There is a paucity of data on the knowledge and practice of preventive measures for Hepatitis $E$ infection. Determination of knowledge and practice of preventive measures are necessary for informed health education for the prevention of Hepatitis E infection and other communicable diseases. The study evaluated the prevalence of Hepatitis E, knowledge, and practice of preventive measures for Hepatitis $\mathrm{E}$ virus infection among adolescents in rural Nigeria.

Methods: This cross-sectional study was conducted over 3 months among rural Nigerian secondary school adolescents. An interviewer-based questionnaire was used to collect data on sociodemographic profile, knowledge, and practice of preventive measures for Hepatitis E infection. Blood samples collected from participants were analysed for Hepatitis E IgG using Elisa Kits (Sigma Diagnostics, USA). Data were analysed using SPSS software version 20.0. Tests of association were done with a level of significance set at $5 \%$.

Results: A total of 9 out of the 414 participants tested positive for Hepatitis E IgG antibodies giving a prevalence of $2.2 \%$. Significant factors for Hepatitis $E$ infection were male gender $\{P=0.004\}$ and school $\{P<0.001\}$. Most participants (98.6\%) had poor knowledge of Hepatitis E infection, $239(57.7 \%)$ had good preventive practices, while $175(42.3 \%)$ had average preventive practices.

Conclusion: Male gender, school, and practice of preventive measures had a significant association with Hepatitis E infection.

\section{Background}

Globally, 20.1 million people are estimated to have Hepatitis E infection every year. Of these, 3.4 million become symptomatic, with mortality being as high as 70,000 , and 3000 stillbirths annually. ${ }^{1}$ About a third of the world's population ( 2.2 billion) comprises children and adolescents. ${ }^{2}$ Hepatitis E infection has been documented as the most common cause of viral Hepatitis with higher prevalence in adolescents and young adults. ${ }^{3,4,5} \mathrm{~A}$ high prevalence rate of $75.6 \%$ and $75.5 \%$ was observed among adolescents aged $10-$ 14 years and 15-19 years respectively in a study done among 5112 healthy children in Egypt by Fix et al. ${ }^{6}$

The concern about the potential long term complications has made its screening to be part of the screening guidelines for blood product transfusion in some developed countries. ${ }^{7}$ This has also led to a growing call for the Hepatitis E vaccine based on the disease burden. Several works have been done worldwide on Hepatitis $E$ infection but in Nigeria, there is a paucity of data. $8,9,10,11,12,13$

Hepatitis E infection is an evolving disease with several risk factors, but the distribution varies depending on population (whether rural or urban), sociodemographic, provision of clean water, food /hygiene practices, sewage disposal, and whether sick or healthy population. ${ }^{8}$ Direct person-to-person 
transmission via the faecal-oral route has been suggested as an additional factor contributing to both epidemic and sporadic cases of HEV. ${ }^{14}$

In developing countries, HEV infection is a public health problem causing both sporadic and epidemic cases that affects several thousands of human lives. ${ }^{15,16}$ Since there is no cure for Hepatitis $E$ infection and vaccines are not readily available, the main strategy for reducing the disease burden is the prevention of the infection. Most studies done focused mainly on the prevalence, while some documented the risk factors. ${ }^{8}$ There is a paucity of data on the knowledge and practice of preventive measures for Hepatitis $E$ infection. Determination of knowledge and practice of preventive measures are necessary for informed health education to reinforce positive habits and discourage negative habits that predispose people to Hepatitis E infection and other communicable diseases. This study evaluated Hepatitis E prevalence, Sociodemographic factors, knowledge, and practice of preventive measures for Hepatitis $E$ infection among adolescents in rural, Southeast Nigeria.

\section{Methods}

The study was a cross-sectional descriptive study conducted from April to July 2017, among secondary school students in Anambra State, South-East Nigeria. Male and female secondary school students aged 10 to 18 years in selected secondary schools participated in this study. Only secondary school students whose ages are from 10 to 18 years who had resided in Anambra state for at least 2 months (incubation period of HEV) were recruited for the study. The school authorities and class teachers were informed about the study before its commencement. Each parent/guardian of participants less than eighteen years signed the informed consent document for his/her child/ward. Assent was given by participants less than 18 years old. An informed consent form was delivered to the parents/guardians through prospective participants.

The sample size was calculated using a prevalence of $7.7 \%$ recorded by Ekanem et al in Nigeria ${ }^{9}$ and assuming a significant level of $3 \%$ and an error of $3 \%$ and a non-response rate of $20 \%$.

\section{Sampling Technique}

A Multi staged sampling technique was used to recruit participants for the study. The schools were selected using a stratified random sampling technique to ensure the recruitment of public and private; same gender and co-educational schools; class, males and females. A total of 6 schools were used for the study. The total population of students in the 21 private schools was 1212, while that of students in the 8 public schools was 1117 giving a ratio of approximately 1:1(1.1:1).

School A is a private, boarding, boys' only school while School B is a public boarding/day boys' only school. School C is a public, day co-educational school and School D is a private day, co-educational school. School E is girls' only private boarding school while School $\mathrm{F}$ is a girls-only public boarding school. 
From school A, 76 students were studied, while 70 students were studied in school B, 85 students in school C, 66 students in school D, 76 students in school E, and 41 students in school F. This selection was based on the population of the schools. Participants that opted out of the study from the six schools were replaced by simple random sampling from the classes in the schools. Study Instruments and Materials:

A semi-structured interviewer-administered questionnaire that was pretested in a school that was not part of the study was used for data collection (see supplementary file). The information included sociodemographic profile, awareness of Hepatitis including routes of transmission, symptoms, personal hygiene factors, social practices, and preventive practices against Hepatitis E. A study identification number was assigned to each subject and this identification number was used to label the specimen bottles.

At the end of the study, there was health education on symptoms, signs, modes of transmission, treatment options, and preventive measures for viral hepatitis with emphasis on Hepatitis E infection.

\section{Laboratory Procedure}

The study was done using ELISA test kits by Sigma diagnostics, USA (Lot Number: JG7190-12) for the detection of IgG to Hepatitis E virus in human serum. The sensitivity and specificity are both $>98 \%$. Sera from all participants were tested for seroreactivity to anti-HEV IgG antibodies (ELISA kits by Sigma Diagnostics, USA). Positive seroreactivity anti-HEV IgG antibodies indicated a previous/past HEV infection. Positive and negative control specimens that were obtained from the SIGMA ELISA kits were run concurrently with the sera during respective batch analysis for anti-HEV IgG antibodies. They were used to assess the validity of the immunoassay procedure and ensure the analytical quality of the ELISA procedure. A negative result indicated that the participant had not been infected by HEV. A positive result was indicative of previous HEV infection. Test results were disclosed to each participant and their parents/guardians.

Knowledge was assessed by summing responses to questions on awareness (maximum of 1 point), routes/modes of transmission (maximum of 4 points), and symptoms/signs (maximum of 5 points), giving a maximum score of 10 points. Scores of $0-4(<40 \%)$ were adjudged as poor knowledge, $5-6$ $(50-60 \%)$ was average knowledge, while 7-10 (>=70\%) was good knowledge. The practice of preventive measures for Hepatitis $E$ ( 7 items) was scored by the summation of responses to questions on preventive measures, giving a maximum of 12 points. Questions on Handwash before meals, Handwash after toilet use, and Fruit and vegetable wash before consumption, were scored using a 2 point Likert scale ("Sometimes"-1, "Always - 2), while the question on eating from a common plate was scored using a reverse Likert 3 point scale (1- Always, 2- sometimes, 3- never). The other responses under the Practice of preventive measures (Consumption of wild game meat, alcohol consumption, and intravenous drug use) scored a maximum of 1 point each. Scores of $0-5(<41 \%)$ were categorized as poor practice, $6-8$ $(50-67 \%)$ were scored as average practice, while $9-12(>=75 \%)$ were adjudged as good practice. 
All completed questionnaires and proforma were coded before entry into IBM SPSS Statistics software version 20.0 for Windows which was used for analysis. Cross-tabulated categorical variables Age group, gender, class, social class (Oyedeji's classification) ${ }^{17}$, seroprevalence, student status, personal hygiene factors\} were tested for association using Pearson's Chi-square (and Fisher's exact test where appropriate) at a statistically significant P-value of $<0.05$, providing a confidence interval of $95 \%$. The dependent variable for the analysis was the presence or absence of Hepatitis E infection. The independent variables were the socio-demographic factors, knowledge, and practice of Hepatitis $\mathrm{E}$ infection preventive measures.

Ethical approval for the study was obtained from the Ethics and Research committee of Nnamdi Azikiwe University Teaching Hospital, Nnewi (NAUTH/CS/66/VOL.9/154/2016/127). Permission was obtained from the Post Primary Schools Board, Nnewi zone, the State Ministry of Education (MOE/SCHD/1570/VOL.I/64), and the Principals of the schools. The guidelines on research involving the use of human subjects were strictly adhered to according to the Helsinki Declaration. Participants did not incur any cost by participating in this study and there was no financial inducement.

\section{Results}

Four hundred and twenty adolescents participated in the study. However, only 414 participants who had determinate results were included in the final analysis. Five samples whose sera could not be separated and one indeterminate result was excluded.

About half of the participants (53.1\%) were males, and almost half (52.7\%) were junior secondary school students. Two hundred and twenty-three students (53.9\%) comprised the 14-16-year age group.

\section{Prevalence Of Hepatitis E}

Of the 414 participants' sera analyzed, 9 were positive for HEV IgG giving a seroprevalence rate of $2.2 \%$. All participants who had positive seroreactivity were males. All anti-HEV seropositive participants attended school B.

\section{Knowledge And Practice Of Preventive Measures For Hepatitis E}

Most participants (98.6\%) had poor knowledge of HEV infection compared to 6/414(1.4\%) who had average knowledge. No participant had good knowledge. Only 37/414 (8.9\%) participants were aware of Hepatitis E infection. Four participants (1.0\%) were aware of its transmission through the waterborne route, while 25/414 (6.0\%) knew it could be transmitted through blood. None was aware of its spread 
through either food or direct contact. Twenty-two participants (5.3\%) identified yellowness of the eyes as a symptom of HEV infection, while only 10/414 (2.4\%) mentioned fever as a symptom (Table 3). On preventive practices towards HEV infection, 160/414(38.6\%) participants "always" washed their hands before meals compared to 254/414 (61.4\%) participants who washed "sometimes" before meals. Two hundred and twenty-four students (54.1\%) always washed hands after toilet use compared to 190/414 (45.9\%) who washed hands "sometimes". Only 141/414(34.1\%) participants ate wild game meat compared to $273 / 414(65.9 \%)$ who did not. Four participants (1.0\%) used illicit intravenous drugs (Table 4).

One hundred and seventy-five participants (42.3\%) had an average practice of HEV preventive measures, while none had poor practice.

\section{Relationships between demographic characteristics, knowledge, and practice of preventive measures with Hepatitis E infection}

There was a significant association between gender and HEV infection $\{P=0.004\}$. However, there was no significant association between age group or socioeconomic class and Hepatitis E infection $\{P>0.05\}$ (Table 1). Of the 239/414(57.7\%) students who had good practices of HEV preventive measures, 2/239 $(0.8 \%)$ had anti-HEV IgG seropositivity compared to $7 / 175$ (4.0\%) seropositivity among participants who had average practice. This difference was statistically significant $\{P=0.04\}$ (See Table 2). There was no significant association between knowledge and HEV infection.

\section{Discussion}

The seroprevalence of Hepatitis E infection was 2.2\% in this study. This seroprevalence rate is lower than $6.5 \%$ recorded by Bugaje et al ${ }^{10}$ among secondary school students in Kaduna state, North-west Nigeria, $7.7 \%$ by Ekanem et a ${ }^{\rho}$ among children in Cross River State, South-south Nigeria; $13.4 \%$ by Adesina et al ${ }^{18}$ in Ekiti state, southwestern Nigeria.

The variations observed in the different studies in Nigeria may be related to the characteristics of the study population which include age, urban versus rural area, gender, sick or healthy population, the study design, presence, and absence of a clinical and subclinical outbreak, and other risk factors.

The age of participants in this study did not influence seroprevalence. This was contrary to reports by Ekanem et $a{ }^{9}$, Bugaje et $a l^{10}$, and Junaid et $a l^{19}$ that had observed a significant association between the age of study participants and HEV infection. A possible explanation for this could be because participants were a homogenous group of adolescents aged from 10 to 18 years old. Different studies that had reported a significant association between age and HEV infection had a wide age range of participants (from 0-20 years and beyond). 5,9,10,19 Participants in the study by Ekanem et a $\beta$ were 
between 1 and 18 years old while the age of study participants in the study by Bugaje et al ${ }^{10}$ ranged from 11 to 20 years.

Only males had anti-HEV IgG seropositivity and this was statistically significant. This is similar to findings by Bugaje et $\mathrm{a}^{10}$ and has also been observed by some scholars in the systematic review by WHO. ${ }^{8}$ The reasons for this higher prevalence among males are unclear as reported by several authors. It could be related to the fact that in our cultural setting, males tend to indulge in risky behaviour such as alcohol ingestion, eating out in food vendors' or retailers' stalls, and sexual debut. ${ }^{20}$ However, Martinson et $\mathrm{al}^{2}{ }^{2}$ in Ghana observed a higher prevalence among females. The reason stated was that in rural Ghana, women are more involved in fetching water from streams, taking care of young children, and thus more likely to be exposed to faeco - oral contamination.

Hepatitis E seropositivity was found to be associated with the school attended. This could point to faecooral and person-to-person modes of transmission. No significant association was found between socioeconomic class and HEV infection. This was similar to findings by Ekanem et $a^{\beta}$ in Cross-river state, Nigeria, and Buti et $a^{21}$ in Spain that observed no association between social class and HEV infection. This could be because most students in this study had similar sources of drinking water and sewage disposal methods irrespective of their social class.

The study showed poor awareness, knowledge of symptoms, and modes of transmission of HEV infection. This may be because Hepatitis $E$ infection is an emerging disease that is not well known in the rural areas. Thus, the need for periodic health education in schools to improve the awareness of HEV infection and other communicable diseases. There was no significant association between knowledge and prevalence of Hepatitis E. The study noted the good practice of preventive measures, and this was significantly associated with the prevalence of Hepatitis E infection.

One of the strengths of this study was that both private and public schools were studied. There was also a good spread between males and females; day and boarding students. The study also evaluated knowledge of Hepatitis $E$ infection among the students. This will aid in policy development for preventive strategies. This study is one of the few studies that focused solely on adolescents. The low prevalence of Hepatitis $E$ in this study could be related to the good practice of the preventive measures for Hepatitis $E$. This is one of the strengths of this index study. Previous studies have focused mainly on the prevalence while few others studied the risk factors. The reason for good preventive practice despite poor knowledge is not clear. This may be linked to good personal hygiene and the practice of preventive measures against other communicable diseases that are transmitted through the faeco-oral route.

\section{Conclusions}

In conclusion, the study noted poor awareness, knowledge of symptoms, and modes of transmission of HEV infection.. There was strong association between the practice of preventive measures, and the prevalence of Hepatitis $E$ infection. 
It is recommended that general health promotion and health education on modes of spread, and preventive strategies for HEV infection and other infectious diseases be incorporated into the school health education aspects of the National school health program, to sustain good preventive practices among adolescents.

A limitation of this study was that only in-school adolescents were evaluated.

\section{Abbreviations}

Anti-HEV antibody to Hepatitis E virus

HEV Hepatitis E virus

IgG Immunoglobulin G

\section{Declarations}

Ethics approval and consent to participate: Ethical approval for the study was obtained from the Ethics and Research committee of Nnamdi Azikiwe University Teaching Hospital, Nnewi (NAUTH/CS/66/VOL.9/154/2016/127). Permission was obtained from the Post Primary Schools Board, Nnewi zone, the State Ministry of Education (MOE/SCHD/1570/VOL.I/64), and the Principals of the schools. The guidelines on research involving the use of human subjects (beneficence, non-maleficence, veracity, confidentiality, voluntarism) were strictly adhered to according to the Helsinki Declaration. Participants did not incur any cost by participating in this study and there was no financial inducement.

Consent for Publication: Not applicable

Availability of data and materials: The datasets used and/or analysed during the current study are available from the corresponding author on reasonable request.

Competing interests: The authors declare that they have no competing interests

Funding: The authors received no funding for this study

Authors' contributions: The manuscript was conceived by MCNP, OH, El, and EJC. All the authors contributed to the study design. Data collection was done by MCNP, EJC, MII, EIJC, and OH while data analysis was done by MCNP, MII, CJO, OH, and NC. The initial draft was produced by MCNP and MII and edited by EJC, El, CJO, EIJC, and NC. All authors agree with the final edited manuscript.

Authors' information:

1) MCNP [MBBS, FWACP(Paed)]

Lecturer/Consultant, Department of Paediatrics, Nnamdi Azikiwe University, Awka, Anambra State, Nigeria 
Email: chiomambachupauline@gmail.com

2) EJC [MBBS, FWACP(Paed)]

Associate Professor/Consultant, Department of Paediatrics, Nnamdi Azikiwe University, Awka, Anambra State, Nigeria

Email: jc.ebenebe@unizik.edu.ng

3) OHC (MBBS, FMCPath)

Senior Lecturer/Consultant, Department of Chemical Pathology, Nnamdi Azikiwe University Awka, Anambra State, Nigeria

Email: hec.okpara@unizik.edu.ng

4) CJO (MBBS, FMCPaed)

Professor/Consultant, Department of Paediatrics, Nnamdi Azikiwe University, Awka, Anambra State, Nigeria.

Email: jochukwuka@gmail.com

5) MII (MBBS, FWACP, FMCOG. FICS)

Senior Lecturer/Consultant, Department of Obstetrics and Gynaecology, Nnamdi Azikiwe University, Awka, Anambra State, Nigeria.

Email: imbachu@yahoo.com, ii.mbachu@unizik.edu.ng

6) EIJC [MBBS, FWACP(Paed)]

Senior Lecturer/Consultant, Department of Paediatrics, Nnamdi Azikiwe University, Awka., Anambra state, Nigeria

Email: jc.elo-ilo@unizik.edu.ng

7) $\mathrm{NCl}(\mathrm{MBBS}, \mathrm{FMCPaed})$

Senior Lecturer/Consultant, Department of Paediatrics, Nnamdi Azikiwe, University Awka, Anambra State, Nigeria.

Email: ifeyc@yahoo.com

8) El (MBBS, FWACP(Paed), FMCPaed) 
Professor/Consultant, Department of Paediatrics, Chukwuemeka Odumegwu Ojukwu University, Awka, Anambra State, Nigeria.

Email: docegbuonu@yahoo.com

Acknowledgements: We acknowledge our research assistants for their hard work.

\section{References}

1. Hepatitis E vaccine: WHO position paper, May 2015 - Recommendations. Vaccine (2015), http://dx.doi.org/10.1016/j.vaccine.2015.07.056

2. UNICEF. The state of the world's children: Statistical tables. 2017; Available from https://data.unicef.org/wp-content/uploads/2018/03/SOWC-2017-statistical-tables.pdf

3. Purcell RH, Emerson SU. Hepatitis E: An emerging awareness of an old disease [Internet]. $J$ Hepatol. 2008;48: 494-503 [cited 2020 Jun 24]. Available from: https://pubmed.ncbi.nlm.nih.gov/18192058/

4. Khuroo MS, Khuroo MS. Hepatitis E: An emerging global disease - From discovery towards control and cure. J Viral Hepat.2016;23(2):68-79. DOl:10.1111/jvh.12445

5. Verghese VP, Robinson JL. A Systematic Review of Hepatitis E Virus Infection in Children. Clin Infect Dis [Internet]. 2014;59:689-97. Available from: http://www.ncbi.nlm.nih.gov/pubmed/24846637. DOI: $10.1093 / \mathrm{cid} / \mathrm{ciu} 371$

6. Fix AD, Abdel-hamid M, Purcell RH, Shehata MH, Abdel-aziz F, Mikhail N, et al. Prevalence of Antibodies to Hepatitis E in two rural Egyptian communities. Am J Trop Med Hyg. 2000;62(4):519-23. DOI: $10.4269 /$ ajtmh.2000.62.519

7. Joint UKBTS Professional Advisory Committee. Change Notification UK National Blood Services No. 29 - 2015. NHS Blood Transpl. 2015;(9):5-7.

8. WHO. The Global Prevalence of Hepatitis E Virus Infection and Susceptibility: A Systematic Review. World Health. 2010. Available from: http://www.who.int/iris/handle/10665/70513

9. Ekanem E, Ikobah J, Okpara H, Udo J. Seroprevalence and predictors of hepatitis e infection in Nigerian children. J Infect Dev Ctries. 2015;9(11):1220-5. DOI:10.3855/jidc.6736

10. Bugaje, Balogun S, Abdulkadir I, Ahmed A. Seroprevalence of Hepatitis E infection among secondary school students in Kaduna State, Northern Nigeria. Sahel Med J. 2016;14(3):143.

11. Asaei S, Ziyaeyan M, Moeini M, Jamalidoust M, Behzadi MA. Seroprevalence of Hepatitis A and E Virus Infections Among Healthy Population in Shiraz, Southern Iran. Jundishapur J Microbiol 2015;8(7):e19311. [cited 2016 Aug 18]; Available from http://www.ncbi.nlm.nih.gov/pubmed/26421130

12. Martinson FE, Marfo VY, Degraaf J. Hepatitis E virus seroprevalence in children living in rural Ghana. West Afr J Med 1999;18(2):76-9 [cited 2016 Aug 8]; Available from http://www.ncbi.nlm.nih.gov/pubmed/10504860 
13. Dong C, Dai X, Liang J, Dong M, Meng J. Seroprevalence of hepatitis e virus varies considerably among Chinese provinces. Hepat Mon 2012;12(6):386-90. [cited 2016 Aug 18]; Available from http://www.ncbi.nlm.nih.gov/pubmed/22879828

14. Teshale EH, Grytdal SP, Howard C, Barry V, Kamili S, Drobeniuc J, et al. Evidence of Person-to-Person Transmission of Hepatitis E Virus during a Large Outbreak in Northern Uganda. Clin Infect Dis [Internet]. 2010;50(7):1006-10. Available from: https://academic.oup.com/cid/articlelookup/doi/10.1086/651077

15. Kamar N, Bendall R, Legrand-Abravanel F, Xia NS, ljaz S, Izopet J, et al. Hepatitis e. Lancet. 2012;379(9835):2477-88. DOI:10.1016/S0140-6736(11)61849-7

16. WHO | Acute hepatitis E - Nigeria. WHO [Internet]. 2017 [cited 2017 Nov 27]; Available from: http://www.who.int/csr/don/12-july-2017-hepatitis-e-nigeria/en/

17. Oyedeji GA. Socio-economic and Cultural Background of Hospitalized Children in llesha. Niger J Paediatr. 1985;12(4):111-7.[cited 2017 Nov 15]; Available from: http://www.njpaediatrics.com/1985/v12n4/2

18. Adesina OA, Japhet MO, Donbraye E, Kumapayi TE, and Kudoro A. Anti hepatitis E virus antibodies in sick and healthy children in Ekiti state. African J Microbiol Res. 2009;3(9):533-6. Available from: http://www.academicjournals.org/ajmr

19. Junaid SA, Agina SE, Abubakar KA. Epidemiology and associated risk factors of hepatitis E virus infection in Plateau State, Nigeria. Virol Res Treat. 2014;5:15-26. DOI:10.4137/VRT.S15422

20. Marano G, Vaglio S, Pupella S, Facco G, Bianchi M, Calizzani G, et al. Hepatitis E: An old infection with new implications. Blood Transfus. 2015;13(1):6-20. DOI 10.2450/2014.0063-14

21. Buti M, Plans P, Domínguez A, Jardi R, Rodriguez Frias F, Esteban R, et al. Prevalence of hepatitis $E$ virus infection in children in the northeast of Spain. Clin Vaccine Immunol [Internet]. 2008;15(4):7324. [cited 2016 Aug 8]; DOI:10.1128/CVI.00014-08

\section{Tables}

Table 1: Relationship between Sociodemographic parameters and anti-HEV IgG 


\begin{tabular}{|c|c|c|c|c|c|}
\hline \multirow[t]{2}{*}{ VARIABLE } & \multirow[t]{2}{*}{$\begin{array}{l}\text { FREQUENCY } \\
(\mathrm{N}=414)\end{array}$} & & HEPATITIS E & \multirow[t]{2}{*}{$x^{2}$} & \multirow[t]{2}{*}{$P$-VALUE } \\
\hline & & POSITIVE(\%) & NEGATIVE(\%) & & \\
\hline \multicolumn{6}{|l|}{ AGE GROUP (years) } \\
\hline $10-13$ & 141 & $4(2.8)$ & 137(97.2) & - & 0.633 \\
\hline $14-16$ & 223 & $5(2.2)$ & 218(97.8) & & \\
\hline$>16$ & 50 & $0(0.0)$ & $50(100.0)$ & & \\
\hline \multicolumn{6}{|l|}{ CLASS } \\
\hline Junior secondary & 218 & $6(2.8)$ & 212(97.2) & - & 0.509 \\
\hline Senior secondary & 196 & $3(1.5)$ & 193(98.5) & & \\
\hline \multicolumn{6}{|l|}{ GENDER } \\
\hline Male & 220 & $9(100.0)$ & 211(95.9) & - & $0.004^{*}$ \\
\hline Female & 194 & $0(0.0)$ & 194(100.0) & & \\
\hline \multicolumn{6}{|l|}{ SCHOOLS USED } \\
\hline A & 76 & $0(0.0)$ & $76(100.0)$ & - & $<0.001 *$ \\
\hline B & 70 & $9(12.9)$ & 61(87.1) & & \\
\hline C & 85 & $0(0.0)$ & $85(100.0)$ & & \\
\hline D & 66 & $0(0.0)$ & $66(100.0)$ & & \\
\hline E & 76 & $0(0.0)$ & $76(100.0)$ & & \\
\hline $\mathrm{F}$ & 41 & $0(0.0)$ & $41(100.0)$ & & \\
\hline \multicolumn{6}{|l|}{ SOCIOECONOMIC } \\
\hline \multicolumn{6}{|l|}{ CLASS } \\
\hline Upper & 74 & $0(0.0)$ & $100(100.0)$ & - & 0.407 \\
\hline Middle & 125 & $3(2.4)$ & 122(97.6) & & \\
\hline $\begin{array}{l}\text { Lower } \\
\text { 209(97.2) }\end{array}$ & 215 & & $6(2.8)$ & & \\
\hline \multicolumn{6}{|l|}{ STUDENT STATUS } \\
\hline Day & 213 & $7(3.3)$ & 206(96.7) & - & 0.177 \\
\hline Boarding & 201 & $2(1.0)$ & 199(99.0) & & \\
\hline Total & 414 & $9(2.2)$ & $405(97.8)$ & & \\
\hline
\end{tabular}


A- $\quad$ Private, boarding, boys' only school, pit latrine use, borehole

* = significant $P$-value

B- $\quad$ Public, boarding/day, boys' only school, pit latrine use, borehole

C- $\quad$ Public, day, co-educational, open defecation, sachet/ water from home

D- Private, day, co-educational, pit latrine use, sachet/water vendor/ home

E- $\quad$ Private, boarding, girls'only, pit latrine use, sachet/borehole

F- Public, boarding, girls' only, water cistern, borehole

Table 2: Participants' Knowledge and Practices towards Hepatitis E infection

\begin{tabular}{|lllll|}
\hline PARAMETER & FREQUENCY (\%) & HEPATITIS E & P- VALUE \\
\hline KNOWLEDGE & & & & \\
\hline Average & 6 & 0.0 & $6(100.0)$ & 1.000 \\
\hline Poor & 408 & $9(2.2)$ & $399(97.8)$ & \\
\hline & & & & \\
\hline PRACTICE & & & & \\
\hline Good & 239 & $2(0.8)$ & $237(99.2)$ & $0.040^{*} \#$ \\
\hline Average & 175 & $7(4.0)$ & $168(96.0)$ & \\
\hline & & & & \\
\hline TOTAL & 414 & $9(2.2)$ & $405(97.8)$ & \\
\hline
\end{tabular}

* = significant $P$-value

\# = Fisher's exact value 
Table 3: Knowledge of Hepatitis E among Participants 


\begin{tabular}{|c|c|c|}
\hline PARAMETER & FREQUENCY & PERCENTAGE \\
\hline \multicolumn{3}{|l|}{ AWARENESS } \\
\hline Yes & 37 & 8.9 \\
\hline No & 377 & 91.1 \\
\hline \multicolumn{3}{|c|}{ ROUTES/MODES OF TRANSMISSION } \\
\hline \multicolumn{3}{|l|}{ Waterborne } \\
\hline Yes & 4 & 1.0 \\
\hline No & 410 & 99.0 \\
\hline \multicolumn{3}{|l|}{ Food Borne } \\
\hline Yes & 0.0 & 0.0 \\
\hline No & 414 & 100.0 \\
\hline \multicolumn{3}{|l|}{ Blood Borne } \\
\hline Yes & 25 & 6.0 \\
\hline No & 389 & 94.0 \\
\hline \multicolumn{3}{|l|}{ Direct contact } \\
\hline Yes & 0.0 & 0.0 \\
\hline No & 414 & 100.0 \\
\hline \multicolumn{3}{|l|}{ SYMPTOMS } \\
\hline \multicolumn{3}{|c|}{ Yellowness of eyes } \\
\hline Yes & 22 & 5.3 \\
\hline No & 392 & 94.7 \\
\hline \multicolumn{3}{|l|}{ Fever } \\
\hline Yes & 10 & 2.4 \\
\hline No & 404 & 97.6 \\
\hline \multicolumn{3}{|l|}{ Weakness } \\
\hline Yes & 8 & 1.9 \\
\hline No & 406 & 98.1 \\
\hline \multicolumn{3}{|l|}{ Headache } \\
\hline Yes & 7 & 1.7 \\
\hline
\end{tabular}




\begin{tabular}{|lll|} 
No & 407 & 98.3 \\
\hline Total & 414 & 100.0 \\
\hline
\end{tabular}

Table 4: Hepatitis E Preventive Practices

\begin{tabular}{|c|c|c|}
\hline PARAMETER & FREQUENCY & PERCENTAGE \\
\hline \multicolumn{3}{|c|}{ Hand wash before meals } \\
\hline Sometimes & 254 & 61.4 \\
\hline always & 160 & 38.6 \\
\hline \multicolumn{3}{|c|}{ Hand wash after toilet use } \\
\hline Sometimes & 190 & 45.9 \\
\hline Always & 224 & 54.1 \\
\hline \multicolumn{3}{|c|}{ Fruit/vegetable wash before consumption } \\
\hline Sometimes & 242 & 58.5 \\
\hline Always & 172 & 41.5 \\
\hline \multicolumn{3}{|c|}{ Use of common plate } \\
\hline Always & 60 & 14.5 \\
\hline Never & 95 & 22.9 \\
\hline Sometimes & 259 & 62.6 \\
\hline \multicolumn{3}{|c|}{ Wild game meat consumption } \\
\hline Yes & 141 & 34.1 \\
\hline No & 273 & 65.9 \\
\hline \multicolumn{3}{|c|}{ Alcohol consumption } \\
\hline Yes & 92 & 22.2 \\
\hline No & 322 & 77.8 \\
\hline \multicolumn{3}{|c|}{ Intravenous drug use } \\
\hline Yes & 4 & 1.0 \\
\hline No & 410 & 99.0 \\
\hline Total & 414 & 100.0 \\
\hline
\end{tabular}


Page 17/17 